\title{
Urinary inorganic phosphorus determinations
}

\author{
D. H. JUNG AND A. C. PAREKHי \\ From the Clinical Laboratory, Indiana University Medical Center, Indianapolis, Indiana, USA
}

SYNOPSIS The Parekh-Jung method for determination of inorganic phosphorus in serum was applied to its determination in urine. Accuracy is good. The mean percentage recovery of added phosphorus was $100.2 \%$. Forty analyses of a sample gave a mean value of $46.71 \mathrm{mg} / 100 \mathrm{ml} \pm 0.76$ standard deviation (between-batch precision). The relative usefulness of the Parekh-Jung method compared with those other methods is discussed.

In an earlier publication Parekh and Jung (1970a, $1970 \mathrm{~b}$ ) introduced the use of p-phenylenediamine dihydrochloride as a reducing agent for the determination of inorganic phosphorus in serum. This new method possessed advantages over the existing methods in terms of simplicity, speed, reproducibility, reagent stability, etc. Recently, the authors applied this method to the determination of inorganic phosphorus in urine.

We now describe our experience with various interfering substances which may be present in urine in considerable concentrations. The results are compared with those obtained by employing the methods of Dryer, Tammes, and Routh (1957), Fiske and Subbarow (1925), and Gomori (1941-42).

\section{Materials and Methods}

\section{REAGENTS}

The reagents used are the same as those used for the determination of inorganic phosphorus in serum.

\section{Trichloracetic acid}

Ten per cent solution in water.

\section{Sulphuric acid solution}

Concentrated sulphuric acid to water in a ratio of $3: 7(v / v)$.

\section{Molybdic acid solution}

Five $\mathrm{g}$ ammonium molybdate is dissolved in $100 \mathrm{ml}$ of the sulphuric acid solution.

${ }^{1}$ Reprint requests should be addressed to A.C.P. at Veterans Hospital, 4150 Clement Street, San Francisco, California 94121, USA

Received for publication 15 July 1971.
Molybdic-trichloracetic acid reagent

One volume of molybdic acid solution is mixed with 2 volumes of $10 \%$ trichloracetic acid solution.

\section{Reducing agent}

p-Phenylenediamine dihydrochloride (Eastman Kodak No.207) $0.5 \mathrm{~g}$ is dissolved in $100 \mathrm{ml}$ of a $5 \%$ sodium meta-bisulphite solution in water.

\section{Phosphorus standard}

For the stock solution, $0.3514 \mathrm{~g}$ of anhydrous monopotassium phosphate is dissolved in $10 \mathrm{ml}$ of $10 \mathrm{~N}$ sulphuric acid and diluted to 1 litre with water to give $8 \mathrm{mg}$ inorganic phosphorus $/ 100 \mathrm{ml}$. For the standard solution, an aliquot of the stock solution is diluted with an equal volume of water to give $4 \mathrm{mg}$ inorganic phosphorus $/ 100 \mathrm{ml}$.

\section{Hyland urine control}

A commercial reference preparation is available from Hyland, Division of Travenol Laboratories, Inc, Costa Mesa, California, USA.

\section{PROCEDURE}

(1) Dilute an aliquot of a 24-hour urine specimen 1:10 (v/v) with water. (2) Deliver $0.1 \mathrm{ml}$ of diluted urine to a $3 \mathrm{ml}$ centrifuge tube, and add $0.9 \mathrm{ml}$ of molybdic-trichloracetic acid reagent. (3) Substitute standard solution and water for urine in the standard and blank tubes respectively in step 2 above. (4) Mix well, allow the tubes to stand for five minutes and centrifuge for five minutes. (5) Transfer $0.5 \mathrm{ml}$ of the supernatant to a $12 \times 75 \mathrm{~mm}$ cuvette and add $2 \mathrm{ml}$ of the reducing reagent. Mix by inversion and allow to stand for 20 minutes for colour development. (6) Read against blank in a spectrophotometer at $680-700 \mathrm{mM}$.

No precipitation occurs with urine in step 4, except in cases of proteinuria. 
CALCULATION

$\frac{\text { OD Unknown }}{\text { OD Standard }} \times$ concentration of standard $\times 10$

$$
\times \frac{\mathrm{ml} \text { of 24-hour specimen }}{1000}=\mathrm{g} \mathrm{P} / 24 \text {-hr urine. }
$$

\section{Results}

Known quantities of inorganic phosphorus in the form of monobasic potassium phosphate were added to aliquots of a urine pool. Analyses were performed in triplicate for each set of the recovery study outlined in Table $\mathrm{I}$. The percentage recoveries ranged from 98.8 to 102.0 with a mean percentage recovery of $100 \cdot 2$.

\begin{tabular}{lcccc}
\hline Urine & Added P & Total Found & Recovered & $\begin{array}{c}\text { Percentage } \\
\text { Recovered }\end{array}$ \\
\hline 3.62 & 4 & 7.60 & 3.98 & 99.5 \\
3.62 & 6 & 9.68 & 6.06 & 101.0 \\
3.62 & 8 & 11.66 & 8.04 & 100.5 \\
3.62 & 10 & 13.50 & 9.88 & 98.8 \\
3.62 & 12 & 15.85 & 12.23 & 102.0 \\
3.62 & 16 & 19.50 & 15.88 & 99.5 \\
\hline
\end{tabular}

Table I Recovery of phosphorus $(\mathrm{mg} / 100 \mathrm{ml})$ added to urine

In order to compare the performance of the four different methods of analysis, a Hyland urine control for inorganic phosphorus (given value of $46 \mathrm{mg} / 100$ $\mathrm{ml}$ with a range of $42-50 \mathrm{mg} / 100 \mathrm{ml}$ ) was employed. Over a period of two months 40 analyses were carried out by each of the methods using the above control. The results obtained were statistically treated and are shown in Table II.

Eight substances were investigated for possible interfering activity in the measurement of inorganic phosphorus in urine. Analyses were performed in triplicate on each set by the four different methods. In Table III the percentage difference from the true value is shown in each case.

\begin{tabular}{lllll}
\hline Method & $\begin{array}{l}\text { Range } \\
(\mathrm{mg} / 100 \mathrm{ml}) P\end{array}$ & Mean & $S D$ & $\begin{array}{l}\text { Coefficient } \\
\text { of Variation }\end{array}$ \\
\hline Parekh-Jung & $45 \cdot 6-48.2$ & 46.71 & \pm 0.76 & 1.62 \\
Fiske-Subbarrow & $45 \cdot 5-48.6$ & 46.96 & \pm 0.86 & 1.85 \\
Gomori & $45 \cdot 4-48.5$ & 46.92 & \pm 0.87 & 1.85 \\
Dryer & $45 \cdot 7-48.4$ & 46.94 & \pm 0.78 & 1.67 \\
\hline
\end{tabular}

Table II Comparison of the four methods showing between-batch precision

\section{Discussion}

In the literature, a separate study of urinary inorganic phosphorus determinations has not usually been described. However, interference by a number of substances in serum or plasma has been reported by Denis and von Meysenbug (1922), Negrin (1964), and Baginski, Foa, and Zak (1967). Such problems encountered in the measurement of inorganic phosphorus in normal urine could be consideraily magnified owing to the very variable composition of urine.

Very little or no interference was observed on applying the proposed method to urinary inorganic phosphorus analyses in the presence of $20 \mathrm{mg} / 100 \mathrm{ml}$ of creatinine, L-histidine, inositol, D-glucose, salicylate, or $50 \mathrm{mg} / 100 \mathrm{ml}$ of oxalate or $100 \mathrm{mg} /$ $100 \mathrm{ml}$ of citrate. Maximum interference was caused by the addition of $20 \mathrm{mg} / 100 \mathrm{ml}$ of L-ascorbic acid and this amounted to less than $1 \%$ of difference from the true value. It is noteworthy that seven of the eight compounds investigated are normally present in urine. The results in Table III are therefore indicative of the accuracy of the method.

The results shown in Tables II and III indicate that the Fiske-Subbarow and Gomori methods are closely comparable. Similarly, it can be concluded that the Dryer method compares favourably with the Parekh-Jung method. However, the Dryer method has certain serious shortcomings. Not only does it lack the simplicity of the Parekh-Jung method, but the insolubility as well as the instability

\begin{tabular}{|c|c|c|c|c|c|}
\hline \multirow[t]{2}{*}{ Substance Added } & \multirow{2}{*}{$\begin{array}{l}\text { Concentration of Added } \\
\text { Substance }(\mathrm{mg} / 100 \mathrm{ml})\end{array}$} & \multicolumn{4}{|l|}{ Method } \\
\hline & & $\begin{array}{l}\text { Dryer } \\
\text { (Percentage difference } f\end{array}$ & $\begin{array}{l}\text { Fiske-Subbarrow } \\
\text { from true value) }\end{array}$ & Gomori & Parekh-Jung \\
\hline $\begin{array}{l}\text { L-Ascorbic acid } \\
\text { Creatinine } \\
\text { Histidine } \\
\text { Inositol } \\
\text { D-Glucose } \\
\text { Salicylate } \\
\text { Oxalate } \\
\text { Citrate }\end{array}$ & $\begin{array}{r}20 \\
20 \\
20 \\
20 \\
20 \\
20 \\
50 \\
100\end{array}$ & $\begin{array}{c}+0.85 \\
0.0 \\
0.0 \\
0.0 \\
0.0 \\
0.0 \\
-0.6 \\
-0.4\end{array}$ & $\begin{array}{r}+1.27 \\
0.0 \\
0.0 \\
+0.4 \\
+0.2 \\
-0.2 \\
-0.4 \\
-0.6\end{array}$ & $\begin{array}{r}+1.06 \\
0.0 \\
0.0 \\
+0.5 \\
+0.4 \\
0.0 \\
-0.4 \\
-0.6\end{array}$ & $\begin{array}{c}+0.85 \\
0.0 \\
0.0 \\
0.0 \\
0.0 \\
0.0 \\
-0.4 \\
-0.4\end{array}$ \\
\hline
\end{tabular}

Table III Effects of interfering substances with different methods when added to urine containing 362 mg phosphorus per $100 \mathrm{ml}$ 
of its reducing agent (Henry, 1964) is such that, for all practical purposes, it would have a limited application. The reagents of the Parekh-Jung method are stable for up to at least six months on the shelf. Also the reducing agent, p-phenylenediamine dihydrochloride, is a stable chemical and is freely soluble in water. The final reaction yields a blue colour, free of turbidity, which is very stable and obeys Beer's law.

The Parekh-Jung method is therefore at least as accurate and precise as the other methods. The procedure is simple and the reagents are stable. After the preliminary dilution, the urine sample is treated exactly as the serum sample thus facilitating simultaneous analyses. Urinary proteins, when present, are removed and hence cause no interference in this method. The Parekh-Jung method is thus ideal for routine use.

\section{References}

Baginski, E. S., Foa, P. P., and ZZak, B. (1967). Determination of phosphate: study of labile organic phosphate interference. Clin. chim. Acta, 15, 155-158.

Denis, W., and von Meysenbug, L. (1922). Note on a possible source of error in the Bell-Doisy method for the determination of phosphates in blood plasma. J. biol. Chem. 52, 1-3.

Dryer, R. L. Tammes, A. R., and Routh, J. I. (1957). The determination of phosphorous and phosphatase with N-phenyl-p-phenyl enediamine. J. biol. Chem., 225, 177-183.

Fiske, C. H., and Subbarow, Y. (1925). The colorimetric determination of phosphorous. J. biol. Chem., 66, 375-400.

Gomori, G. (1941-42). A modification of the colorimetric phosphorous determination for use with the photoelectric colorimeter. J. Lab. clin. Med., 27, 955-960.

Henry, R. J. (1964). Determination of inorganic phosphorous. In Clinical Chemistry: Principles and Technics, pp. 411-412. Hoeber, New York.

Negrin, A. (1964). Studies on the spectrophotometric determination of phosphorous using hydriodic acid as a reducing agent, and a proposed new method applicable to serum and urine. Clin. chim. Acta, 10, 262-270.

Parekh, A. C., and Jung, D. H. (1970a). Serum inorganic phosphorous determination using $p$-phenylenediamine as a reducing agent. Clin. chim. Acta, 27, 373-377.

Parekh, A. C., and Jung, D. H. (1970b). Erratum. Clin. chim. A ta, 28, 509. 